Engineering Sustainability

Volume 164 Issue ES1

Transition in public participation in

Chinese water management

Song, Mulder, Frostell, Ravesteijn and

Wennersten

ice proceedings
Proceedings of the Institution of Civil Engineers Engineering Sustainability 164 March 2011 Issue ES1 Pages 71-83 doi: 10.1680/ensu.2011.164.1.71 Paper 1000027

Received 10/05/2010_Accepted 10/09/2010

Keywords: hydrology \& water resource/infrastructure planning/public-private partnerships

ICE Publishing: All rights reserved

\title{
Transition in public participation in Chinese water management
}

1 Xingqiang Song $\mathrm{MSC}$

PhD Candidate, Department of Industrial Ecology, Royal Institute of Technology, Stockholm, Sweden

2 Karel Mulder PhD

Associate Professor, Department of Technology Dynamics \& Sustainable Development, Delft University of Technology, Delft, the Netherlands

3 Björn Frostell PhD

Associate Professor, Department of Industrial Ecology, Royal Institute of Technology, Stockholm, Sweden
4 Wim Ravesteijn PhD

Associate Professor, Department of Technology Dynamics \& Sustainable Development, Delft University of Technology, Delft, the Netherlands

5 Ronald Wennersten $\mathrm{PhD}$

Professor, Department of Industrial Ecology, Royal Institute of Technology, Stockholm, Sweden
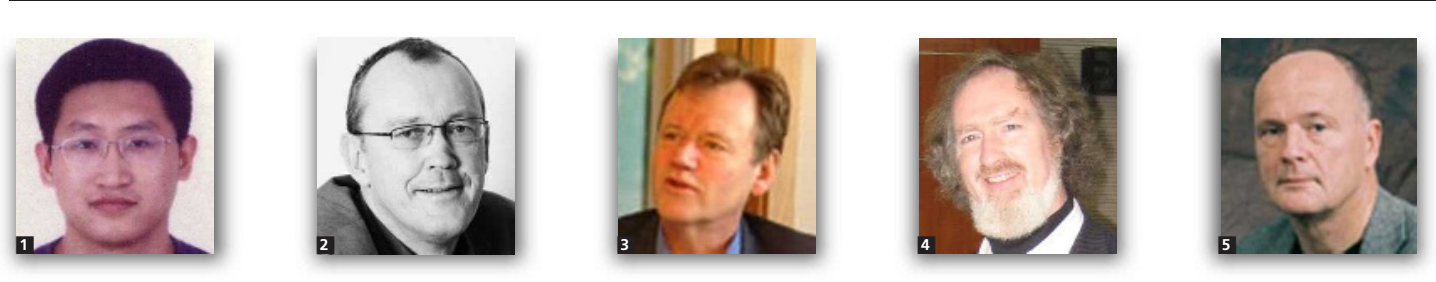

In recent years, the Chinese central government has expressed the goal of working towards a civil society. However, there are great challenges in a transition to participatory decision-making in water systems management, and this paper aims to analyse the difficulties in the Chinese context. The development of Chinese water systems is summarised, with a focus on the characteristics of water management framework and its underlying values. The initiation of public participation in environmental decision-making is tracked, as well as its scope in the planning process of three water-related projects. Finally, the participatory mechanisms and capacity in China are briefly discussed from different perspectives. This paper argues that effective public participation in China is substantially hindered by current participatory mechanisms and capacity. Improved decision-making would result from: amendments to legal requirements on compulsory participation and broadening environmental information disclosure; developing sufficient relevant monitoring systems towards evidence-based planning and decision-making; inclusion of all relevant stakeholders under transparent planning and decision-making regimes; and building institutional capacity with the emphasis on developing a feasible procedural framework for participation and for assessing the effectiveness of the participatory process.

\section{Introduction}

Emerging worldwide water stress problems have gradually been acknowledged as being the result of ineffective and weak water management (Falkenmark, 1990; Satterthwaite and McGranahan, 2007; UNDP, 2006). This has led to a paradigm shift from sectoral and centralised water management to integrated and adaptive water management. In particular, since the 1990s, sustainability science (Clark and Dickson, 2003) has frequently been discussed in water sector management (e.g. focusing on the dynamic interactions between nature and society). The Dublin principles (UN, 1992) emphasise the importance of a participatory approach in water development and management, involving users, planners and policy-makers at all levels. Another new paradigm that has attracted wider attention since 2000 is based on the philosophy that water allocation and management are political processes and that participatory and inclusive approaches between political and other institutions are needed for conflict resolution (Allan, 2006). Correspondingly, a 'soft path' - ensuring public participation in decisions over water - is now underway and aiming to complement the conventional 'hard path' that is prone to make decisions on generic needs with little transparency or public input (Palaniappan and Gleick, 2009). As Boland and Baumann (2009) pointed out, perhaps the greatest change in public participation in water resources management has been the role of the public in water planning processes.

Considering the key role of water infrastructure in socioeconomic development, wise water infrastructure planning and decision-making involving the public at the lowest appropriate 
Engineering Sustainability

Volume 164 Issue ES1
Transition in public

participation in Chinese water

management

Song, Mulder, Frostell, Ravesteijn

and Wennersten level is essential in improving the performance of water systems at all levels. The traditional centralised physical infrastructure approach has been criticised for its neglect of unanticipated ecological, social and financial costs of projects (Gleick, 2003). A participatory approach, which is more than just consultation, is regarded as the only means for achieving long-lasting consensus and common agreement (GWP, 2000). Indeed, public participation has become a core component of the official discourse on sustainable development (Macnaghten and Jacobs, 1997). Moreover, the concept of participation is tied to notions of citizenship that try to deal with some competing values of legitimate and competent government, and to structures of participation that are designed to reflect regime values (Banyan, 2007). One important feature of the European Union (EU) water framework directive, for example, is recognising the importance of developing effective mechanisms to support public and stakeholder participation in water planning and decision-making process at the river basin level (EU, 2000; Videira et al., 2006).

Public participation has often been discussed in the context of environmental impact assessment (EIA) (Martens, 2006; Tang et al., 2005; Wang et al., 2003; Zhao, 2010) and social impact assessment (SIA) (Tang et al., 2008) in China. However, public influence on decision-making in the water sector is still limited in the context of Chinese EIA Law adopted in 2002 and other relevant regulations. Here, the question is whether and how participatory approaches can be effectively adopted in China, with the aim of improved decision-making.

This paper investigates the existing barriers to effective public participation in China's water infrastructure development planning and explores how participatory approaches could be facilitated in the contemporary Chinese context. The development of Chinese water systems is first summarised, focusing on the characteristics of the water management framework and its underlying values. The paper then tracks the initiation of public participation in environmental decisionmaking, as well as its scope in the planning process of three water-related projects. Finally, participatory mechanisms and capacity in China are briefly discussed from different perspectives and suggestions for future work are presented.

\section{Water management development in the Chinese context}

China is currently still at the 'hydraulic mission' stage of water management. One basic concept of the hydraulic mission is that nature can be controlled (Allan, 2006), and an engineeringorientated approach to water management has been facilitated since the 1950s. Chairman Mao's policy to 'conquer and harness nature' (Shapiro, 2001) initiated a programme of intensive water infrastructure constructions on different scales in order to meet increasing demand for water and to prevent flooding and droughts. Almost all of the world's large dams (higher than
$15 \mathrm{~m}$ ) built since 1950 are located in China (Gleick, 2009), and of the 84000 reservoirs in use in China until 1999, more than 70\% were built between 1957 and 1977 (Liu and Zhang, 1999).

Since the introduction of market economic reforms and the opening-up policy put forward by Deng Xiaoping in 1978, China has been experiencing rapid economic growth; this has greatly facilitated the development of water systems, especially largescale hydraulic engineering projects designed for multiple purposes. During the 'crossing the river by feeling for stones' (i.e. emphasising careful pragmatism) period in the 1980s and 1990s, China's socioeconomic development essentially benefited from Deng's pragmatic 'cat theory': 'the cat is good regardless of being white or black, as long as it can catch mice,' signifying that development would take priority above ideology on capitalism.

Over the past three decades, multi-purpose water engineering projects (e.g. the Three Gorges dam) have become even more popular in China. In the coming decades, hydraulic construction will remain dominant, especially for the purposes of water supply, navigation, river control and the production of cleaner hydropower (Wang, 2007). As a developing country, the improved performance of water infrastructure will contribute to socioeconomic development in many regions of China. In this context, integrated strategies and participatory approaches are imperative if water systems with minimal environmental impact and various other conflicts are to be developed.

Since the 1980s, China has experienced a variety of water stress problems (e.g. water scarcity, flooding, water pollution and degraded aquatic and terrestrial ecosystems), partly due to the huge population, fast urbanisation and industrialisation, and intensively altered land use. China's water systems are currently in the grip of a severe crisis that may threaten the country's environmental and socioeconomic development in the long term. In 2008 , more than $20 \%$ of the $150000 \mathrm{~km}$ of monitored river sections was seriously polluted and, essentially, useless (MWR, 2009). The water table in the North China Plain is dropping by $1.5 \mathrm{~m}$ every year and the water table in Beijing has dropped $37 \mathrm{~m}$ over the past four decades (Barlow and Clarke, 2002). Unfortunately, the fragile water systems may be further damaged by climate change in the future. Moreover, competition for water and resulting water conflicts at all levels have intensified in recent years.

Although China has made many efforts to improve the performance of its water management, there are still a variety of challenges to overcome in the light of emerging water stress problems. One challenge is to improve its water administration framework (Figure 1), characterised as a top-down system with fragmented water institutions and overlapping responsibilities (Song et al., 2010). Besides the Ministry of Water Resources (MWR), there are several other departments related to water management at national level. These include 


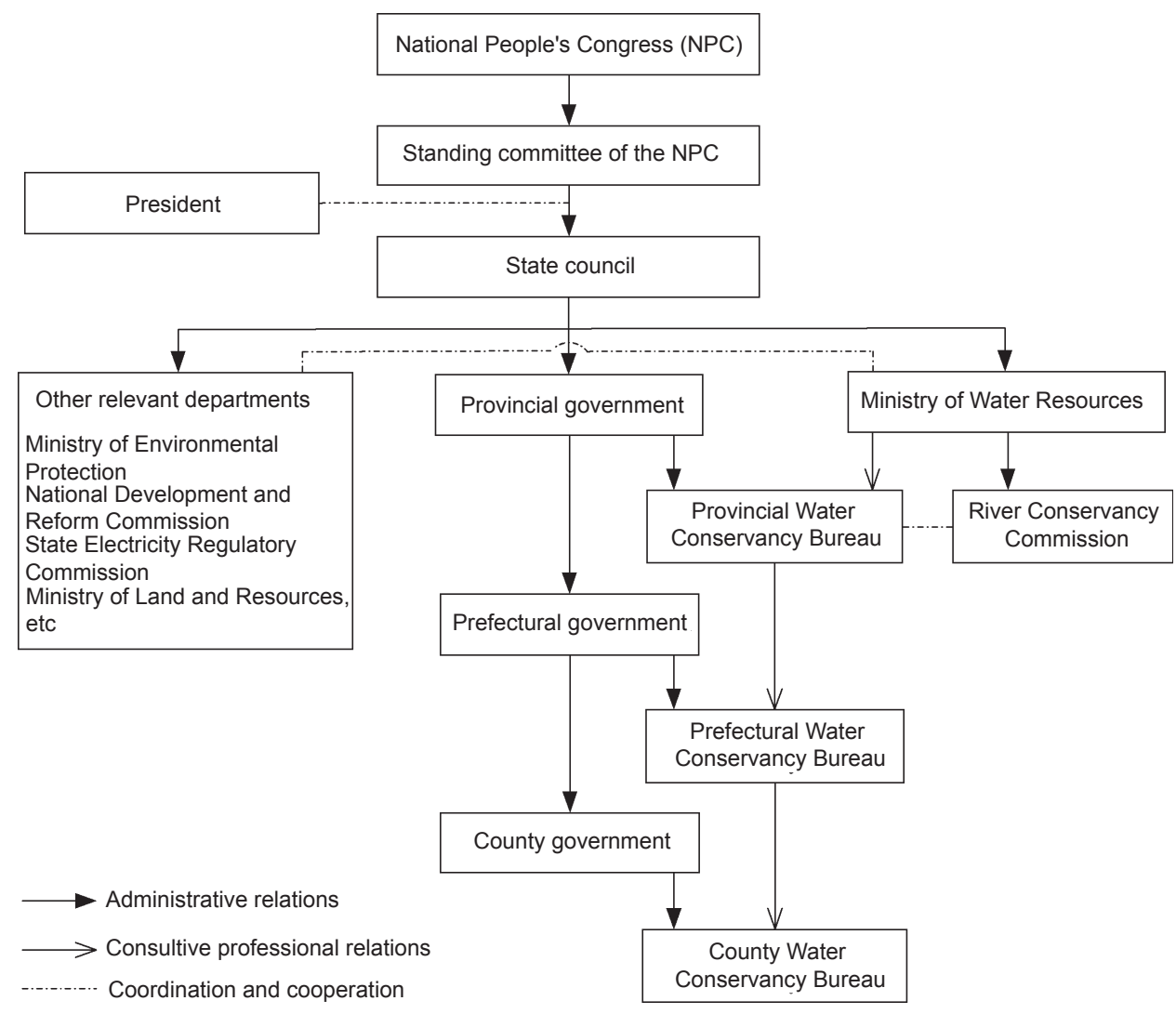

Figure 1. A simplified picture showing the structure of China's water management system

(a) the Ministry of Environmental Protection (MEP), which replaced the former State Environmental Protection Administration (Sepa) in March 2008

(b) the National Development and Reform Commission (NDRC), responsible for a programme of water resources utilisation

(c) the State Electricity Regulatory Commission (SERC), responsible for electricity generation including hydropower

(d) the Ministry of Land and Resources (MLR), responsible for rational utilisation of land resources and overdraft of groundwater.

China has a highly centralised political system with several distinct hierarchical levels. In some sense, this system could be very powerful, for instance by implementing laws and regulations on water allocation and pollution prevention. However, China has partly adopted decentralised public affairs management at regional and local level. The regional and local governments are responsible for adapting and implementing national policy, laws and regulations in their specific environmental and socioeconomic context. At regional and local level, various water conservancy bureaus are affiliated to the government at different levels, while the MWR functions simply in consultative professional relations with various water conservancy bureaus. Within the current water administrative framework, there are various conflicts among actors at different levels. In particular, conflicts among regions relevant to upstream and downstream water allocation and environmental protection have been intense in many river basins. Improvement of China's water management mechanisms is thus an important social challenge in which ecological, technical-economic and social situations have to be considered in an integrated way.

\section{Initiation of public participation in Chinese environmental decision-making}

The emerging serious water-related problems have forced the Chinese authorities to pay more attention to balancing economic development and environmental protection, and this has been emphasised in the eleventh set of 5-year guidelines (MEP, 2008) for national economy and social development (2006-2010). Unfortunately, many decision-makers at regional and local level still set the highest priority on economic development. Not surprisingly, the public's desire for a better living environment has been frequently neglected or refused by many decision-makers, especially in remote rural areas. In this 
Engineering Sustainability

Volume 164 Issue ES1
Transition in public

participation in Chinese water

management

Song, Mulder, Frostell, Ravesteijn

and Wennersten context, China's aquatic and terrestrial ecosystems are gradually being degraded by a number of polluting small-scale factories and hydraulic infrastructure development without systematic environmental considerations. In turn, these degraded ecosystems may impair the national capacity for socioeconomic development in the long term.

In recent years, the Chinese government has indicated a strong desire to facilitate improvements in democracy, political legitimacy and public participation in public affairs management. The Chinese President $\mathrm{Hu}$ Jintao, for example, has drawn from the traditional Chinese philosophies of Confucianism (emphasising social order or hierarchy) and Daoism (advocating naturalistic tradition or 'the way it is') and has put forward a theory of 'social harmony' to address problems of increasing inequality and growing conflicts in China (Chen and Lee, 2008). On 19 February 2005, President $\mathrm{Hu}$ delivered an important speech at the opening ceremony of a high-level seminar of the Communist Party of China (CPC) in which he said 'The CPC and the central government have made it an important task to build a harmonious society, which serves the fundamental interests of the people' (People's Daily, 2005). At the 17th national people's congress of the CPC in 2007, President Hu further illuminated the goals of building a well-off society by 2020 . Besides the goal of quadrupling the per capita value of gross domestic product (GDP) of the year 2000, he also emphasised the need to narrow widening income gaps, improve social justice, expand democracy and enhance the 'soft power' of Chinese culture (Tian, 2007).

When it comes to environmental protection, the EIA Law, adopted in 2002 and promulgated for effect on 1 September 2003, strengthens the scope and content for appraising the environmental impacts of programmes and construction projects, as well as emphasising public participation in the environmental appraisal of projects (article 1). The most important general principles of environmental decision-making and public participation according to the EIA Law (NPC, 2002) are the following.

(a) The appraisal of the environmental impacts must be objective, open and impartial, and must assess the impacts on various environmental factors and the corresponding ecosystems of the programmes or construction projects after they are carried out (article 4).

(b) The state encourages relevant entities, experts and the general public to participate in the appraisal of environmental impacts in appropriate ways (article 5).

(c) The scope of the plans or programmes - relating to land use and exploitation, river basin development, energy, water conservancy, natural resources development and so on - developed by relevant departments or governments above county level should be submitted to the state council for ratification (article 9). (d) Except for confidential projects, for any construction project with potential significant environmental impacts, developers should collect the opinions of relevant organisations, experts and the general public in advance. Thereafter, the project EIA reports must be submitted for scrutiny and approval and should include an explanation of how they would respond to the collected opinions (article 21).

(e) If the EIA of any construction project fails to pass the official examination, the project cannot start (article 25).

Besides the 2002 EIA Law, several pieces of legislation and regulation have been developed relevant to facilitating the progress of public participation in EIA. The Administrative Licence Law of China (NPC, 2003), enforced in July 2004, recognises the right of the public to be involved in public affairs (e.g. concerning environmental protection (article 12) by means of public hearings (articles 46-48)). In March 2006, Sepa issued implementation measures for public participation in EIA (Sepa, 2006), which emphasised the guidelines on environmental information disclosure and specified the forms and procedures of public participation. In February 2007, Sepa released measures on open environmental information (for trial implementation), effective on 1 May 2008, which stated that both government and enterprise environmental information should be open to the public (Sepa, 2007). Moreover, the MWR issued several regulations on public participation, e.g. implementation measures of the administrative licence law in the water sector (MWR, 2005) and regulation on public hearings for administrative permits in the water sector (MWR, 2006).

Although there is growing support for public participation in theory, it is still very challenging for the Chinese society to move towards a participatory decision-making regime. The following three cases represent examples regarding the recent situation of water infrastructure project planning in China and the extent of public participation. The cases addressed are a municipal lake project, a regional dam project planning and the national south-to-north water transfer project (SNWTP). Study of these three cases aims to characterise the current state of public participation and identify challenges for improved public participation in Chinese water management, especially in infrastructure development planning.

\section{Snapshots of public participation in three water projects}

\subsection{Public hearing in lake leakage prevention, Beijing} In 2005, Sepa organised the first national-level public hearing on the environmental impact of an ongoing lake water leakage prevention project in Beijing's Old Summer Palace. The public hearing may be regarded as an example of emerging public participation in EIA of water projects in China. One main topic of the public hearing was to discuss the possible environmental 
Engineering Sustainability

Volume 164 Issue ES1
Transition in public

participation in Chinese water

management

Song, Mulder, Frostell, Ravesteijn

and Wennersten impact of a project to prevent lake water leakage through the use of plastic and cement. The total investment in the project was around 30 million Chinese Yuan $(\mathrm{CNY})(\approx £ 2.8$ million$)$.

The event began when Professor Zhengchun Zhang from Lanzhou University noticed the ongoing project during a visit to the palace park on 22 March 2005. On 29 March, he published a paper via People's Daily Online discussing possible environmental impacts of the project. The project was then widely reported by the media and non-government organisations (NGOs). On 31 March, Sepa confirmed that the project under construction had violated the EIA Law because the developer had not submitted an EIA report for examination and approval. Sepa announced that the project should stop immediately and required that relevant EIA documents be produced. On 1 April, the construction project was halted when the developer received notice from the Sepa. However, the project was almost finished by then. On 6 April, Sepa announced that a public hearing would be held on 13 April. More than 70 representatives - including water and ecological experts, NGOs, the general public and relevant institutions took part in the public hearing. It was not until 9 May that Sepa required the project developer to submit EIA documents within 40 days. On 17 May, Sepa announced that Tsinghua University would take responsibility for preparing EIA reports for the project. On 5 July 2005, after examining the submitted EIA reports, Sepa agreed with the conclusions of these reports and suggested that the developer rebuild parts of the project by means of natural methods to prevent leakage.

This case demonstrates both progress and shortcomings of public participation in EIA of civil engineering projects in China. Progress can be seen by the fact that the original plans were altered as a result of the public hearing and that the project was finally completed according to the law. In terms of shortcomings, there was no specific focus in the public hearing due to EIA documents being unavailable and no public hearing was organised before the project's EIA documents were submitted for scrutiny and approval. More importantly, however, the case probably demonstrates that a public hearing can alleviate conflicts between the public and governmental decision-makers in an orderly way, without threatening the stability of social order (Moore and Warren, 2006). This case also demonstrates the important role of the public in environmental supervision, for example by publicising and reporting on projects with potential environmental impacts. On the other hand, the case may reflect some deep-rooted problems concerning China's environmental decision-making on civil engineering construction projects. How could such a civil engineering project with large potential socio-ecological impacts be carried out without EIA approval and never be questioned by any environmental protection department or agency before the event? How many similar projects are ongoing?

\subsection{Controversies over dam planning along the $\mathrm{Nu}$ River, Yunnan province}

Originating in the Tibet plateau, the $2820 \mathrm{~km}$ long Salween River flows through Yunnan province in China (this section is called the $\mathrm{Nu}$ River), Burma and Thailand. It is one of the longest freeflowing rivers in the world (WWF, 2006). In 2003, the site of the three parallel rivers of Yunnan protected areas was included in the World Heritage list as a natural property (UNEP/WCMC, 2010).

The ecosystem of the Nu River now faces the risk of being strongly affected by the possible construction of hydropower dams. The plan, proposed by the government of Yunnan province and the state-owned Huadian Electricity Corporation (HEC) of China, is to build 13 dams in the middle and lower reaches of the Nu River (the fifth longest river in China), with a total installed capacity of around 21000 MW by the year 2020. In August 2003, the NDRC approved the planning application of the dam construction submitted by the Yunnan government. This approval date was around 1 month before the EIA Law adopted in 2002 came into effect. In early 2004, the Chinese Premier Wen Jiabao halted the dam construction project and called for more cautious investigation and scientific decision-making (Liu, 2005). Environmental NGOs were also very active: 61 Chinese NGOs and 98 environmental public figures jointly wrote a letter of concern to the state council, Sepa and NDRC (Buckley, 2006). From 2005, a series of public hearings and surveys of the $\mathrm{Nu}$ River have been conducted.

There has been ongoing debate about the dam project since 2004, involving the Yunnan government, HEC, Sepa, experts, NGOs and the media, among others. The Yunnan government and HEC claim that the hydropower projects would substantially improve socioeconomic development in regions along the $\mathrm{Nu}$ River, where around 50000 local inhabitants are still very poor. Moreover, most experts in the region have expressed their support, mainly from a cost-benefit perspective and possible reductions in carbon dioxide emissions through the development of hydropower stations. On the other hand, Sepa, some experts in Beijing, journalists and NGOs have strongly argued against the project in order to bestow a pristine river ecosystem to future generations. In December 2008, the state-owned China Central Television channel 10 (CCTV-10) broadcast a series of programmes called ' $\mathrm{Nu}$ River story - waking up the river' in which eight experts from local governments, water management and research authorities and other disciplines claimed that

(a) the hydropower projects would present no threat to the World Heritage site, local culture or local flora and fauna

(b) relocated residents would be treated well, with homes and food guaranteed (Ding, 2009).

However, in April 2009, Premier Wen halted the whole series of hydropower projects along the $\mathrm{Nu}$ River once again and suggested that the relevant authorities 'widely heed opinions, 
Engineering Sustainability

Volume 164 Issue ES1
Transition in public

participation in Chinese water

management

Song, Mulder, Frostell, Ravesteijn

and Wennersten thoroughly expound on the plan and make prudent decisions' (Salween Watch, 2010).

To date, the project has still not been officially approved by the state council, while the Yunnan government and project developer have been seeking more support to develop the hydroelectric industry in the region. The final decision on this project will be one indicator of contemporary choices by China's central government (especially between economic development and long-term ecosystem protection) and of the official attitude towards voices of the public, as well as ways of conflict resolution and negotiation of main stakeholders at local, regional and national levels.

The case of the dam planning along the Nu River raises another issue: how to organise public participation and make more objective EIA reports with fewer questions from the public. In this case, the Yunnan government and Sepa have held a number of symposia involving participation by experts, officials, representatives of local inhabitants, the media, etc. However, these meetings rarely reach consensus, partly due to often contradictory opinions between experts and organisers from different regions. Moreover, the opinions of two representatives of local inhabitants who expressed support for the dam project at a meeting in Beijing in 2006 were later proved to be partially based on an investigation in their village by a Beijing-based journalist (Liu, 2007).

\subsection{Dilemmas in the south-to-north water transfer project}

It has taken around half a century to make decisions on the SNWTP, and there are still discussions on uncertainties of the project taking place (Berkoff, 2003; Lasserre, 2003; Liu and Zheng, 2002). The initial idea of water diversion was put forward by Chairman Mao in 1952, and various feasibility studies proposing and comparing different schemes have been put forward since then. Looking into the planning process since the 1950s, most of the feasibility studies have been made mainly from economic and engineering technical perspectives relevant to different schemes for transferring water. Regarded as a national basic infrastructure, central government and several national departments responsible for water administration have coordinated the processes of project planning and decision-making. In particular, the MWR and its affiliated River Basin Commissions (RBCs) have prepared planning reports for the four river basins involved. On 23 December 2002, the state council ultimately approved the overall plan of the SNWTP. However, there is no official explanation as to why this decision was made only by the state council, rather than the National People's Congress of China, as was the approval procedure for the Three Gorges dam.

The SNWTP is planned to transfer water from the upper (west route), middle (middle route) and lower (east route) reaches of the Yangtze River to north and north-west China, which are subject to water scarcity. Water will be transferred by means of canals and tunnels over a total length of about $4000 \mathrm{~km}$. It will be the largest long-distance water diversion project in China, with a total investment of around 500 billion CNY $(\approx £ 47$ billion). A large amount of land will be occupied by the project and around 400000 villagers in more than 100 counties will be relocated (NSBD, 2010). The project will link four main Chinese river basins: the Yangtze, the Yellow, the Huai and the Hai. When the project is completed in 2050, around 44.8 billion $\mathrm{m}^{3}$ of water ( 17 billion $\mathrm{m}^{3}$ by the west route, 13 billion $\mathrm{m}^{3}$ by the middle route and 14.8 billion $\mathrm{m}^{3}$ by the east route) will be transferred annually from the Yangtze River basin to regions in the north. The total investment in the east, middle and west route projects will be around 42, 92 and 304 billion $\mathrm{CNY}(\approx £ 3 \cdot 9,8 \cdot 6$ and $28 \cdot 6$ billion) respectively.

Although many experts have been involved in the investigation and planning process (Shui, 2008), the SNWTP has been controversial with regard to all three proposed routes, even after their approval by the state council. The east and middle routes, now under construction, relate to seven regions Beijing, Tianjin, Hebei, Henan, Hubei, Shandong and Jiangsu. To date, one of the main controversies regarding these routes is the planning approach adopted (i.e. making decisions and starting project construction before discussing the feasibility studies). Phase I projects of the east and middle routes began in December 2002 and December 2003, respectively. In August 2003, the EIA report of projects in Beijing (middle route) passed examination by a temporary committee of around 40 experts from Sepa, MWR, the Municipal Environmental Protection Bureau of Beijing and the Hai River Conservancy Commission. In November 2006, Sepa passed the EIA report of the phase I projects of the east route. In 2007, Jiangsu and Shandong provinces, involved in the east route project, each held a symposium (for the first time) aimed at informing the public about current progress of the project, as well as clarifying three relevant topics - land use and demolition, resettlement, and environmental protection. However, it was not until October 2008 that the feasibility study reports of the east and west routes were approved by central government.

In 2009, the SNWTP construction commission announced that the middle route, scheduled to be finished in 2010, would be postponed and finished in 2014. The official explanations for this are obscure, but there are at least three reasons (Tian, 2009): the doubled cost of building the SNWTP; more difficulties in relocating the people affected because of a low rate of compensation; and increasing requests by the affected governments and experts for more feasibility studies of the socioeconomic impacts caused by the planned project's construction.

The west route project, planned to start construction in 2010 , has also been controversial during recent years. One popular 
Engineering Sustainability

Volume 164 Issue ES1
Transition in public

participation in Chinese water

management

Song, Mulder, Frostell, Ravesteijn

and Wennersten public opinion is to suspend this route in order to undertake more comprehensive investigation into its impacts. In 2001, the MWR approved the planning report of the west route finished by the Yellow River conservancy commission. This planning report was not open to the public until 2005 and since then many experts have questioned it from different perspectives. In August 2006, over 50 natural and social scientists contributed to a book exploring a variety of problems relevant to water quality, water quantity, ecological environment, etc. of the west route (Lin et al., 2006). In October 2006, three prestigious Chinese academics - Qian Zhengying, Pan Jiazheng and Shen Guofang - on behalf of the Chinese Academy of Engineering, proposed that the state council should postpone west route project construction (Wang, 2009). These activities may prompt central government to undertake further feasibility analyses. To date, the official decision on the west route is unknown.

Besides carrying out more comprehensive studies on the project's (non-)feasibility, another important issue may be how to resolve the emerging conflicts between the decisionmakers and the public, especially local experts. Looking into the planning and decision-making process, the SNWTP was initiated by national government and mainly coordinated by relevant ministries with a few invited experts. Most decisions are usually communicated to the public. Under these circumstances, national and regional conflicts between the national agencies and regional governments can theoretically be negotiated and consensus can be reached, coordinated by the state council in its current top-down administrative framework. In the case of the west route of the SNWTP, for example, the main opposing opinions come from a variety of experts and scholars with emphasis on the project's overall feasibility and long-term ecological impacts on the affected regions. Therefore, one core problem of such large-scale water projects would be how to efficiently collect and effectively work with positive and negative opinions, especially from people with specialist knowledge, in the short term.

\section{Discussion}

The three cases presented above reveal four important influencing factors in current Chinese water-related decision-making (Figure 2). Three main pillars of water-related decision-making in China can be identified as legal requirements, institutional capacity and cultural heritage; information functions as a foundation in this framework. The extent of information accessible to the public, the amount of information only available within institutions and the capacity to collect data required but currently unknown form the basis to understanding the specific socio-ecological situation and to addressing various conflicts.

In general, public participation aims to improve the quality, legitimacy and capacity of environmental assessments and decisions (Dietz and Stern, 2008). In this regard, information with user-friendly elucidation is the main way to alleviate discord with the public and to achieve improved decisionmaking with sufficient support. However, in terms of the eight rungs on the ladder of citizen participation developed by Arnstein (1969), public participation in the three cases presented here is still in its infancy. The type of public participation, especially in the EIA of water infrastructure projects, is moving from the non-participation level ('manipulation' and 'therapy') to the slightly higher level aimed at 'informing.' There are undoubtedly various challenges in China moving towards effective public participation in water sector management. Apart from further raising public environmental awareness, difficulties in broader and effective public participation in China mainly concern two aspects: underdeveloped participatory capacity and insufficient participatory mechanisms.

\subsection{Underdeveloped capacity for public participation} Despite being supported by several pieces of sectoral legislation and regulation, broader public participation in EIA of waterrelated construction projects has been essentially hindered in practice due to a lack of participatory capacity. Underdeveloped capacity building for public participation in water management can be traced to several aspects. These include insufficient legal support regarding compulsory public participation and adequate environmental information disclosure, and a lack of guidelines for efficiently collecting and addressing different opinions from the public.

The several officially approved laws, regulations and measures mentioned in this paper are all guidelines rather than compulsory requirements to involve the public in the process of project planning and EIA. This trend can be found, more or less, in the three cases studied. The initiation of public hearings and symposia usually starts as a result of voices from the public rather than

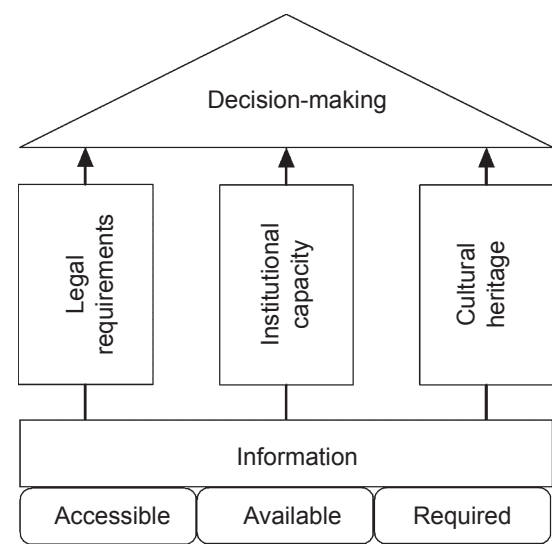

Figure 2. Identified influencing factors in current Chinese water-related decision-making 
Engineering Sustainability

Volume 164 Issue ES1
Transition in public

participation in Chinese water

management

Song, Mulder, Frostell, Ravesteijn

and Wennersten activities organised by decision-makers or project developers in the early planning stage. Although the state encourages the public to participate in EIA of plans and construction projects (through article 5 of the 2002 EIA Law), it is not actually illegal for planners and project developers to refuse to involve the public.

\subsubsection{Methods of organising public participation}

In the implementation measures for public participation in EIA (Sepa, 2006), three forms of participation are suggested: surveying public opinion and consulting experts (articles 19 and 20); holding symposia and demonstration meetings (articles 21-23); organising public hearings (articles 24-32). In practice, the most common organised form of public participation is to send questionnaires to the general public at community and municipal levels. Expert consultation and public hearings are the other main methods for public participation in the process of EIA report approval.

However, the problem is how to evaluate the equity and fairness of different forms of public participation and therefore judge overall effectiveness. The public participation process can sometimes risk being manipulated to choose participants, for instance experts and representatives of the general public, in order to generate the preferred answers of decision-makers and planners. According to the 2002 EIA Law, expert advisory groups responsible for examining reports on the environmental impact of projects should be randomly chosen from databases of experts developed by the environmental administrative departments of the state council (article 13). However, the experts employed are seldom randomly chosen from this database. What is more, EIA reports and project plans are usually completed by research institutions invited and paid by government agencies or project investors. Understandably, some experts can be reluctant to propose conflicting opinions to their employers in writing up the required EIA reports if they want to be employed to write more EIA reports. Interestingly, some Chinese village officials are on the one hand government employees and, on the other, representatives of the people (Plummer, 2004). This indicates that citizen participation is relatively low in water infrastructure planning and decision-making, especially at regional and national levels.

\subsubsection{Environmental information disclosure and capacity of monitoring networks}

Due to a lack of sufficient legislative support, there are many uncertainties regarding practical public participation and environmental information disclosure. In terms of the 2002 EIA Law, there is no statutory requirement for full EIA reports to be made available to the public (Wang et al., 2003), especially before official approval by the relevant agencies. For example, the lake leakage prevention project started in September 2004, but it was not publicly known until March 2005. On the other hand, there are several articles in the EIA Law and the implementation measures for public participation in EIA emphasising that the disclosed governmental environmental information may not endanger state security, economic security, public security or social stability. However, there are no specifications on the kinds of information that are of 'state' or 'economic' security. In this context, the public would be prevented from accessing detailed information in time if the required information had been classified as 'secret' by officials and developers.

In all situations, a proper and sufficient river water monitoring network is essential to make more information available for effectively addressing the complexity and uncertainties of water systems. More specifically, the impacts of water infrastructure projects at all levels are usually complex and relevant to several disciplines, which need broader approaches taking account of geomorphological, hydrological and ecological perspectives. Updated disclosure of relevant planning reports is crucial to achieve efficient public participation. Meanwhile, the recognition of information required but currently unknown is also helpful to complement the future development of relevant monitoring networks at all levels. As can be seen from the three cases presented here, one focus of conflict is the long-term socioecological impacts of water infrastructure projects. Very often, neither project developers and environmental protection agencies nor the public can provide convincing relevant information to strongly support their opinions. In the public hearing for the lake leakage case, the only evidence-based report was presented by a local NGO, which took photos and documented changes in the environment surrounding the lake since 2003 (FON, 2010). Similarly, many controversies in the other two cases discussed failed to be resolved, partly due to a lack of sufficient support based on reliable data (e.g. from monitoring and scientific investigation). These limitations should be highly stressed in these and other cases in order to place more emphasis on developing sufficient and systematic environmental monitoring, as well as data management systems at all levels.

\subsection{Insufficient mechanisms for public participation}

The underdeveloped participatory capacity largely relates to insufficient mechanisms for public participation in China. China has a long-term tradition of a highly centralised political system with a strictly hierarchical regime. Within this framework, various decisions in China are easily made or directed in terms of the will of a few powerful stakeholders. Cai (2009) concludes that urban planning has had almost no effect on the rapid urbanisation taking place in China over recent decades. Not surprisingly, many Chinese officials are uneasy about interacting with the public (e.g. at EIA hearings) because they fear this could actually lead to changes in decisions that have already been made (Kim and Jones, 2006).

Culture plays a fundamental role regarding public participation in natural resources planning and management. China has 
Engineering Sustainability

Volume 164 Issue ES1
Transition in public

participation in Chinese water

management

Song, Mulder, Frostell, Ravesteijn

and Wennersten been administered under a highly centralised political system for thousands of years. One traditional philosophy in China is Confucianism, which favours a unified political system with strict inferiority and superiority creating a social hierarchy. During most of the period from the Han dynasty (202 BCAD 220) to the Qing dynasty (AD 1644-1919), Confucianism was adopted as the official philosophy to reinforce the imperial system, to rule the people and select officials. Historically, Confucianism has strongly influenced the development of traditional Chinese culture and social values and it may still contribute to the development of different political and environmental values in contemporary China.

For several decades, Chinese policy-makers, decision-makers and water managers, aided by expert assessment/reviews, have been undertaking planning and decision-making in the water sector without adequate transparency and inputs from the wider public. Until the end of the 1970s, the powerful nationwide authority of the MWR over water control and infrastructure development planning and decision-making was seldom challenged, and the capital and labour that were required for key projects were usually made readily available (Boxer, 2001). Since the 1990s, with increasing environmental awareness and more frequent environmental crises, people in China are becoming much more concerned about environmental protection. As a consequence, the authority of the traditional ways of water infrastructure planning and decisionmaking has frequently been challenged over the past decade. One example of this is the enormous controversy surrounding the Three Gorges dam with regards to its environmental impact, resettlement of affected farmers and villagers, loss of biodiversity and destruction of cultural relics (Boland, 1998).

The closed planning and decision-making framework in China is probably the main reason why there are so many controversies over some water infrastructure developments. Experience in the Netherlands has shown that the decisionmaking process of large infrastructure projects can be substantially hindered if stakeholders are only addressed late in the process, when decisions have in fact already been taken (van Ast and Boot, 2003). A more transparent planning and decision-making process, especially involving more people with specialist knowledge, would be helpful to improve decisionmaking and public consensus.

\subsection{The future of public participation in environmental decision-making}

Many of the relevant important principles for participatory water resources management have been proposed and tested in the developed world. There are also many successful cases regarding participatory water management in Europe and the USA, with a regime of representative democracy. Participatory democracy, developed as a complement to representative democracy, argues for the broad participation of the public in environmental and other forms of public decision-making (Overdevest, 2000). However, the transition to participatory decision-making in China is likely to be very difficult even in the long term in view of its socio-political regime and currently weak civil society.

In recent years, another theory has begun to make inroads in China, even as electoral democracy seems blocked at national level (Dryzek, 2009). Deliberative democracy is the theory and practice of a model of democracy that emphasises the exchange of reasons in the making of democratic decisions (Crocker, 2008). The goal of deliberative democracy is to revitalise civic culture, improve the nature of public discourse and generate the political will necessary to take effective action on pressing problems (Weeks, 2000). Deliberation is used most often to describe the process used by juries, councils, legislatures and other bodies that make decisions after a period of reasoned discussion (Gastil and Keith, 2005). Manin et al. (1987) advocate the legitimacy of results from a deliberative process in which all citizens (or at least those who wish to do so) are able to take part, choose among several solutions and remain free to approve or refuse the conclusions developed from the argument.

However, the concept of deliberative democracy currently seems to be misunderstood in China. Although China has now had four deliberative polls (Fishkin et al., 2010), the scale of the activities is rather low and mainly organised at village or community level. Leib (2005) summarised several phenomena with regard to deliberative democracy in China; two are introduced here. Firstly, Chinese politicians, themselves members of the CPC, were those with the greatest enthusiasm. Secondly, due to the problem that mass participation is sometimes frowned upon in China's history (e.g. the Cultural Revolution (1966-1976)), deliberative participation of the few may be the right course for the Chinese to skirt the fear of the many. The underlying values of deliberative democracy have probably been regarded by Chinese decision-makers as a kind of practical political regime aimed at alleviating conflicts between decision-makers and the public. In this regard, the Chinese understanding of deliberative democracy seems similar to the approach of consultation employed, for instance, in the Chinese People's political consultative conference (CPPCC), whereby the progress of broader democracy to some extent still depends on the will of decision-makers. It is still too early to determine whether the principles of deliberative democracy have been adopted in the Chinese socio-political regime to facilitate the development of a civil society.

China is still in its infancy as regards the development of civil society in general and the role of NGOs in particular. With rapid economic development, the Chinese discourse on democracy has profoundly changed over the past two decades and much of it now focuses on institutional and procedure 
Engineering Sustainability

Volume 164 Issue ES1
Transition in public

participation in Chinese water

management

Song, Mulder, Frostell, Ravesteijn

and Wennersten matters $(\mathrm{Li}, 2008)$ rather than political institutional reforms. However, the future development of civil society and its direction, quality and relationship to the state are contingent on changes in China's political institutions, legal infrastructure and economy (Gallagher, 2004). Thus, it will probably take much longer for China to achieve full development of a civil society. The flourishing numbers of environmental NGOs have played an important role in facilitating public participation in the project planning process, as shown in the first two of the cases presented in this paper. However, the role of environmental NGOs in China is still very limited because they are constrained by their dependence on government benevolence and paucity of human capital (Schwartz, 2004)

Although political reform is sometimes advocated to remake China's public philosophy (Zhou, 2003), it could be argued that an incrementally evolutionary approach, ensuring socioeconomic development in a relatively stable political atmosphere, would be more effective than a radical revolutionary movement. Mertha (2008) points out that, as China has become increasingly market-driven and politically heterogeneous, water control and management has been transformed from an unquestioned economic imperative into a lightning rod of bureaucratic infighting, societal opposition and open protest. In the short term, there will be great challenges in the transition from a top-down to a participatory decision-making regime by means of, for instance, institutional leapfrogging and the development of democratic culture.

With rapid socioeconomic development, China is now at a crossroads regarding participatory decision-making in both environmental and other public affairs management. To facilitate the development of participatory decision-making regimes, it is crucial to strengthen participatory mechanisms and build participatory capacity in a framework of sustainable development. In order to achieve more consensus and successfully address various conflicts, the Chinese government should legally improve its environmental decision-making process regarding transparency and accountability. One important aspect in this regard is to encourage its current administrative system in a transition from a control regime to an adaptive regime (e.g. allowing more effective public participation in water resources development, planning and management). In the larger context, this aspect is important for constructing a 'harmonious' (i.e. wealthy, equitable and civil) society in the whole of China in the long term.

In order to make decisions with more consensus in the contemporary Chinese context, efforts are required at all levels to facilitate broader public participation. At both strategic and operational levels, essential points include legislative demand for compulsory public participation in EIA of all projects, enlarging relevant environmental information disclosure and effectively organising broader public participation in the planning process of engineering projects. An overall institutional and procedural framework for participation is required. Although the 2002 EIA Law and several other guidelines have emphasised the need for public participation, China still lacks sufficient experience to organise efficient and effective public participation at the lowest appropriate level. The creation of an independent committee at national level would probably be helpful in guiding and evaluating the progress of public participation, resolving various conflicts and achieving consensus between planners, decision-makers and the public.

It is crucial to include all relevant stakeholders and individuals with specialist knowledge in the planning process, especially when water projects have potential multiple socio-ecological impacts in the long term. In practice, this is often not possible and some trade-offs between principles and practice have to be made. It seems evident that including more stakeholder interaction and public participation would improve the current Chinese water management situation. When working towards effective conflict resolution and rational decisions, it is very important to develop a feasible and accountable procedural framework in which different actors are allowed to express and negotiate their different concerns. Comprehensive stakeholder dialogue will bring different views into the stakeholder interplay arena and uncover more possible arguments. Once these arguments are in the public arena, they can no longer be neglected in the decision-making process. Decision-makers must take the results of the participation process into consideration. Such a broader process would, of course, require time, resources, education and practical training, but would result in a more balanced and widely accepted decision.

\section{Conclusions}

A transition to a more participatory approach would improve water management and gain greater acceptance for decisions taken in China. However, as demonstrated in this paper, the scope and extent of Chinese public participation are still limited due to underdeveloped participatory capacity and insufficient participatory mechanisms. This paper has discussed the challenges of a transition towards more participatory decision-making in terms of four aspects: legal requirements; institutional capacity; the extent of accessible and available information; and cultural heritage.

Facilitating legal requirements towards broader participation in China currently relates to two issues: the extent of public participation and environmental information disclosure. In terms of the 2002 EIA Law, the public is only encouraged to participate in EIA of water projects. Similarly, several other officially approved regulations and measures are guidelines rather than legal compulsory requirements to involve the public in the process of project planning and EIA. Moreover, the legal requirements on 
Engineering Sustainability

Volume 164 Issue ES1
Transition in public

participation in Chinese water

management

Song, Mulder, Frostell, Ravesteijn

and Wennersten relevant environmental information disclosure to the public are ambiguous. These factors often impede contributions from the public. One way to improve decision-making would be to instigate legislative requirements for compulsory public participation and sufficient environmental information disclosure at an early stage of the planning process for all water-related projects.

In practice, broader public participation in EIA of waterrelated projects has been hindered due to underdeveloped institutional capacity regarding the organisation of public participation. At present, most water infrastructure plans and decisions are communicated to the public, with critical analysis and assessment being carried out by a small number of stakeholders. Although public hearings have been organised in recent years, as a natural part of the planning process they are few in number. Until a new and more mandatory public participation process is legally implemented, a possible approach would be to emphasise the overall benefits of a participatory process more clearly. The development of a feasible documentation and audits framework for public participation would also be very valuable.

The currently limited extent of accessible information has partly restricted achieving scientifically sound decisions with more consensus. To a large extent, sufficient accessible and available socio-ecological data form the basis for rational decisionmaking, especially when negotiating a variety of viewpoints from a scientific perspective. However, rational decisions are often affected by limited information, especially for large-scale projects with multiple socioeconomic impacts. Thus, special attention needs to be paid by decision-makers to developing sufficient relevant monitoring and reporting systems, accompanied by scientific explanations of the available information.

Confucianism has strongly influenced the development of traditional Chinese culture and social values. This traditional philosophy has resulted in a unified political system with strict inferiority and superiority creating a social hierarchy. Very often, the currently centralised administrative framework works in a closed decision-making process, which has limited public participation. To address the challenges of broader public participation in China, one starting point could be to promote adaptiveness, transparency and accountability.

The current strong dynamics of socio-ecological development in China complicate the process of decision-making and public participation in water development planning and management. To improve decision-making involving the public, more comprehensive studies are needed in the context of sustainable development. In particular, three further research areas would be helpful

(a) socially orientated studies on the development of Chinese decision-making in the water sector and how it has been influenced by social structure, politics, religion and environmental concerns

(b) better studies documenting the planning, implementation and monitoring of large water projects

(c) studies on possibilities for mutual learning between China and the west.

\section{REFERENCES}

Allan JA (2006) IWRM: the new sanctioned discourse? In Integrated Water Resources Management: Global Theory, Emerging Practice and Local Needs (Mollinga PP, Dixit A and Athukorala K (eds)). Sage Publications, New Delhi, pp. $38-63$.

Arnstein SR (1969) A ladder of citizen participation. Journal of American Planning Association 35(4): 216-224.

Banyan ME (2007) Participation. In Encyclopedia of Governance (Bevir M (ed.)). Sage Publications, Thousand Oaks, CA, pp. 659-663.

Barlow M and Clarke T (2002) Blue Gold: The Battle Against Corporate Theft of the World's Water. Earthscan, London.

Berkoff J (2003) China: the south-north water transfer project is it justified? Water Policy 5(1): 1-28.

Boland A (1998) The Three Gorges debate and scientific decisionmaking in China. China Information XIII(1): 25-42.

Boland JJ and Baumann D (2009) Water resources planning: past, present and future. In The Evolution of Water Resource Planning and Decision Making (Russell CS and Baumann DD (eds)). Edward Elgar, Cheltenham, pp. 14-81.

Boxer B (2001) Contradictions and challenges in China's water policy development. Water International 26(3): 335-341.

Buckley L (2006) Spotlight on NGO Activism in China. China Environmental Series 8: 114-116.

Cai D (2009) Public participation and its development in China. In Public Participation: Constructing a Framework for the 'Risk Society' (Cai D (ed.)). Law Press, Beijing, pp. 1-24 (in Chinese).

Chen CC and Lee YT (2008) Introduction: the diversity and dynamism of Chinese philosophies on leadership. In Leadership and Management in China: Philosophies, Theories, and Practices (Chen CC and Lee YT (eds.)). Cambridge University Press, Cambridge, pp. 1-27.

Clark WC and Dickson NM (2003) Sustainability science: the emerging research program. Proceedings of the National Academy of Sciences 100(14): 8059-8061.

Crocker DA (2008) Ethics of Global Development: Agency, Capability, and Deliberative Democracy. Cambridge University Press, Cambridge.

Dietz T and Stern PC (2008) Executive summary. In Public Participation in Environmental Assessment and Decision Making (Dietz T and Stern PC (eds.)). National Academies Press, Washington, DC, pp. 1-5.

Ding Y (2009) The real Nu River story. See http://www. chinadialogue.net/article/show/single/en/2750-The-real-NuRiver-story for further details (accessed 28/07/2010). 
Engineering Sustainability

Volume 164 Issue ES1
Transition in public

participation in Chinese water

management

Song, Mulder, Frostell, Ravesteijn

and Wennersten
Dryzek J (2009) The Australian citizens' parliament: a world first. Journal of Public Deliberation 5(1): 1-9.

EU (European Union) (2000) Directive 2000/60/EC of the European Parliament and of the Council of 23 October 2000: establishing a framework for Community action in the field of water policy. Official Journal of the European Communities, L327.

Falkenmark M (1990) Global water issues confronting Humanity. Journal of Peace Research 27(2): 177-190.

Fishkin JS, He B, Luskin RC and Siu A (2010) Deliberative democracy in an unlikely place: deliberative polling in China. British Journal of Political Science 40(2): 435-448.

FON (Friends of Nature) (2010) www.fon.org.cn (accessed 08/10/ 2010).

Gallagher ME (2004) China: the limits of civil society in a late Leninist state. In Civil Society and Political Change in Asia: Expanding and Contracting Democratic Space (Alagappa M (ed.)). Stanford University Press, Stanford, CA, pp. 419-452.

MEP (Ministry of Environmental Protection) (2008) China National Environmental Protection Plan in the Eleventh Five Years (2006-2010). China Environmental Science Press, Beijing.

Gastil J and Keith WM (2005) A nation that (sometimes) likes to talk: a brief history of public deliberation in the United States. In The Deliberative Democracy Handbook: Strategies for Effective Civic Engagement in the TwentyFirst Century (Gastil J and Levine P (eds.)). Wiley, San Francisco, CA, pp. 3-19.

Gleick PH (2003) Global freshwater resources: soft-path solutions for the 21st century. Science 302(5650): 1524 1528.

Gleick PH (2009) China and water. In The World's Water 2008 2009: The Biennial Report on Freshwater Resources (Gleick PH et al. (eds.)). Island Press, Washington, DC, pp. 79 100.

GWP (Global Water Partnership) (2000) Integrated Water Resources Management. GWP, Stockholm, Technical advisory committee (TAC) background paper no. 4. See http://www.gwpforum.org/gwp/library/Tacno4.pdf for further details (accessed 20/07/2010).

Kim MJ and Jones RE (2006) Public participation with Chinese characteristics. China Environmental Series 8: 98-102.

Lasserre F (2003) Alleviating water scarcity in northern China: balancing options and policies among Chinese decisionmakers. Water Science and Technology 47(6): 153-159.

Leib EJ (2005) The Chinese Communist Party and deliberative democracy. Journal of Public Deliberation 1(1): 1-7.

Li C (2008) Introduction: assessing China's political development. In China's Changing Political Landscape: Prospects for Democracy (Li C (ed.)). Brookings Institution Press, Washington, DC, pp. 1-21.

Lin L, Liu B, Ma H and Liu S (eds) (2006) Memorandum of the West Route Project of the South-to-North Water Transfer. Economic Science Press, Beijing (in Chinese).
Liu Y (2005) Missing Voices on the Nu River Dam Project. See http://www.worldwatch.org/node/14 for further details (accessed 02/08/2010).

Liu J (2007) Fog on the Nu River. See http://www.chinadialogue. net/article/ show/single/en/811-Fog-on-the-Nu-River for further details (accessed 28/07/2010).

Liu BJ and Zhang JH (1999) Reservoir construction and floods prevention in China. China Water Resources 7(433): 16-17 (in Chinese).

Liu C and Zheng H (2002) South-to-north water transfer schemes for China. Water Resources Development 18(3): 453-471.

Macnaghten P and Jacobs M (1997) Public identification with sustainable development: investigating cultural barriers to participation. Global Environmental Change 7(1): 5-24.

Manin B, Stein E and Mansbridge J (1987) On legitimacy and political deliberation. Political Theory 15(3): 338-368.

Martens S (2006) Public participation with Chinese characteristics: citizen consumers in China's environmental management. Environmental Politics 15(2): 211-230.

MEP (Ministry of Environmental Protection) (2008) China National Environmental Protection Plan in the Eleventh Five Years (2006-2010). China Environmental Science Press, Beijing.

Mertha AC (2008) China's Water Warriors: Citizen Action and Policy Change. Cornell University Press, New York.

Moore A and Warren A (2006) Legal advocacy in environmental public participation in China: raising the stakes and strengthening stakeholders. China Environmental Series 8: 3-23.

MWR (Ministry of Water Resources) (2005) Implementation Measures of the Administrative Licence Law in the Water Sector. See http://www.gov.cn/gongbao/content/2006/ content_310608.htm for further details (accessed 13/11/ 2010) (in Chinese).

MWR (2006) Regulation on Public Hearings for Administrative Permits in the Water Sector. See http://www.gov.cn/ gongbao/content/2007/content_660555.htm for further details (accessed 13/11/2010) (in Chinese).

MWR (2009) China's Water Resources Statistics Bulletin in 2008. See http://www.mwr.gov.cn/zwzc/hygb/szygb/ qgszygb/201001/ t2010 0119 _171051.html for further details (accessed 06/08/2010) (in Chinese).

NPC (National People's Congress) (2002) Law of the People's Republic of China on Environmental Impact Assessment. See

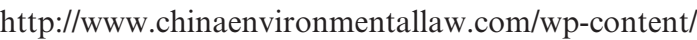
uploads/2008/03/environmental-impact-assessment-law.doc for further details (accessed 14/11/2010).

NPC (2003) Administrative License Law of the People's Republic of China. See http://www.lawinfochina.com/law/display. asp?id $=3076$ for further details (accessed 14/11/2010).

NSBD (South to North Water Transfer) (2010) http://www. nsbd.gov.cn/ (accessed 08/10/2010) (in Chinese). 
Engineering Sustainability

Volume 164 Issue ES1
Transition in public

participation in Chinese water

management

Song, Mulder, Frostell, Ravesteijn

and Wennersten
Overdevest C (2000). Participatory democracy, representative democracy, and the nature of diffuse and concentrated interests: a case study of public involvement in a national forest district. Society \& Natural Resources 13(7): 685-696.

Palaniappan M and Gleick PH (2009) Peak water. In The World's Water 2008-2009: The Biennial Report on Freshwater Resources (Gleick PH et al. (eds)). Island Press, Washington, DC, pp. 1-16.

People's Daily (2005) Building Harmonious Society Important Task for CPC: President Hu. See http://english.peopledaily. com.cn/200502/20/eng20050220_174036.html for further details (accessed 07/08/2010).

Plummer J (2004) Introduction. In Community Participation in China: Issues and Processes for Capacity Building (Plummer $\mathrm{J}$ and Taylor JG (eds)). Earthscan, London, pp. 1-20.

Salween Watch (2010) www.salweenwatch.org (accessed 08/10/ 2010).

Satterthwaite D and McGranahan G (2007) Providing clean water and sanitation. In State of the World 2007: Our Urban Future (Starke L (ed.)). WW Norton, New York, pp. 26-47.

Schwartz J (2004) Environmental NGOs in China: roles and limits. Pacific Affairs 77(1): 28-49.

SEPA (State Environmental Protection Administration) (2006) Implementation Measures for Public Participation in Environmental Impact Assessment. See http://www.gov.cn/ jrzg/2006-02/22/content_207093.htm for further details (accessed 14/11/2010) (in Chinese).

SEPA (2007) Measures on Open Environmental Information (for Trial Implementation). See http://www.

chinaenvironmentallaw.com/wp-content/uploads/2008/04/ environmental-information-disclosure.pdf for further details (accessed 12/11/2010) (in Chinese).

Shapiro J (2001) Mao's War against Nature: Politics and the Environment in Revolutionary China. Cambridge University Press, Cambridge.

Shui QS (2008) Moving the flow: China Reshapes its Water Supply. China International Press, Beijing.

Song X, Ravesteijn W, Frostell B and Wennersten R (2010) Managing water resources for sustainable development: the case of integrated river basin management in China. Water Science and Technology 61(2): 499-506.

Tang SY, Tang CP and Lo CW (2005) Public participation and environmental impact assessment in mainland China and Taiwan: political foundations of environmental management. Journal of Development Studies 41(1): 1-32.

Tang B, Wong S and Lau MC (2008) Social impact assessment and public participation in China: a case study of land requisition in Guangzhou. Environmental Impact Assessment Review 28(1): 57-72.

Tian L (2007) Hu: Well-off society is top goal. See http://www. chinadaily.com.cn/china/2007-10/16/content_6177389.htm for further details (accessed 07/08/2010).

Tian L (2009) Why is the south-to-north water transfer project postponed? South Wind Window 25(12): 59-61 (in Chinese).
UN (United Nations) (1992) The Dublin Statement on Water and Sustainable Development. See http://www.un-documents. net/h2o-dub.htm for further details (accessed 08/10/2010).

UNDP (United Nations Development Programme) (2006) Human Development Report 2006 - Beyond Scarcity: Power, Poverty and the Global Water Crisis. Palgrave Macmillan, New York.

UNEP/WCMC (United Nations Environment Programme/World Conservation Monitoring Centre) (2010) www.unep-wcmc. org (accessed 08/10/2010).

van Ast JA and Boot SP (2003) Participation in European water policy. Physics and Chemistry of the Earth 28(12-13): 555562.

Videira N, Antunes P, Santos R and Lobo G (2006) Public and stakeholder participation in European water policy: a critical review of project evaluation processes. European Environment 16(1): 19-31.

Wang H (ed.) (2007) China's Water Resources and Sustainable Development. Science Press, Beijing (in Chinese).

Wang X (2009) The Postponed West Route. See http://www. lwdf.cn/oriental/current_events/ 20090611152820206.htm for further details (accessed 06/08/2010) (in Chinese).

Wang Y, Morgan RK and Cashmore M (2003) Environmental impact assessment of projects in the People's Republic of China: new law, old problems. Environmental Impact Assessment Review 23(5): 543-579.

Weeks EC (2000) The practice of deliberative democracy: results from four large-scale trials. Public Administration Review 60(4): 360-372.

WWF (World Wildlife Fund) (2006) Free-flowing rivers: economic luxury or ecological necessity? See http://assets. panda.org/downloads/freeflowingriversreport.pdf for further details (accessed 08/08/2010).

Zhao Y (2010) Public participation in China's EIA regime: rhetoric or reality? Journal of Environmental Law 22(1): 89123.

Zhou J (2003) Remaking China's Public Philosophy for the Twenty-first Century. Praeger, Westport.

\section{WHAT DO YOU THINK?}

To discuss this paper, please email up to 500 words to the editor at journals@ice.org.uk. Your contribution will be forwarded to the author(s) for a reply and, if considered appropriate by the editorial panel, will be published as discussion in a future issue of the journal.

Proceedings journals rely entirely on contributions sent in by civil engineering professionals, academics and students. Papers should be 2000-5000 words long (briefing papers should be 1000-2000 words long), with adequate illustrations and references. You can submit your paper online via www.icevirtuallibrary.com/content/journals, where you will also find detailed author guidelines. 